\title{
- PRÓBA OCENY JAKOŚCI ŻYCIA RODZIN DZIECI, KTÓRYM ZAŁOŻONO GASTROSTOMIE
}

\author{
ATTEMPT TO ASSESS LIFE QUALITY OF FAMILIES WITH CHILDREN AFTER GASTROSTOMY
}

\author{
Maria Jolanta Lorenc ${ }^{1}$, Joanna Gotlib² \\ ${ }^{1}$ Wydział Nauki o Zdrowiu, \\ Warszawski Uniwersytet Medyczny \\ ${ }^{2}$ Zakład Dydaktyki i Efektów Kształcenia \\ Warszawski Uniwersytet Medyczny
}

DOI: https://doi.org/10.20883/pielpol.2017.25

\section{STRESZCZENIE}

Wstęp i cel. Przezskórna endoskopowa gastrostomia (PEG) jest jedną z metod żywienia dojelitowego. Jest ona z powodzeniem stosowana zarówno u dorosłych, jak i u dzieci, a także noworodków o skrajnie niskiej wadze urodzeniowej. Celem pracy była próba oceny jakości życia rodzin dzieci z założoną gastrostomią (PEG).

Materiał i metody. Badaniami objęto 87 osób - rodziców dzieci, u których założono przezskórną gastrostomię odżywczą (PEG), 71 kobiet i 16 mężczyzn w wieku od 23 do 53 lat (średnia =32,03; $\mathrm{SD}=6,12$; min. 23, max. 53). Rodzice dzieci przed założeniem PEG (to grupa 1) oraz rodzice dzieci po złożeniu PEG (to grupa 2). Dzieci były pacjentami Poradni Chirurgicznej Instytutu Pomnika Centrum Zdrowia Dziecka w Warszawie. Anonimowe, dobrowolne badania ankietowe przeprowadzono od 15.09 .2014 r. do 27.02.2015 r.

Wyniki. W opinii 69 (79\%) badanych rodziców jakość życia dziecka i rodziny po założeniu PEG wzrosła. Subiektywna ocena jakości życia rodziny przed założeniem PEG wyniosła 3,23, a po założeniu PEG - 3,79 $(\mathrm{p}<0,001)$. W opinii 75 badanych (85\%) zdecydowanej poprawie uległ stan zdrowia pacjenta oraz jego stan odżywienia ( $n=69,78 \%$ ). Głównym źródłem wiedzy na temat choroby oraz emocjonalnego wsparcia dla rodziców dzieci z PEG były pielęgniarki $(n=59,67 \%)$ oraz lekarze $(n=53,60 \%)$ i inni rodzice $(n=29,33 \%)$.

\section{Wnioski}

1. Jakość życia dziecka oraz funkcjonowanie rodziny po założeniu gastrostomii odżywczej PEG u dziecka uległa $w$ badanej grupie istotnej poprawie.

2. Założenie gastrostomii odżywczej PEG u dziecka znacznie wpłynęło również w badanej grupie na ogólny stan zdrowia dziecka i stan jego odżywienia, co mogło istotnie wpływać na wzrost jakości życia rodziny.

3. Ważnym elementem w opiece nad dzieckiem z gastrostomią odżywczą PEG jest wiedza rodziców na temat choroby, jej objawów, przebiegu i rokowania, a także udzielone rodzinie wsparcie, dlatego też niezwykle istotna wydaje się być edukacyjna rola pielęgniarki.

SŁOWA KLUCZOWE: żywienie enteralne, jakość życia, rodzina, dziecko.

\section{ABSTRACT}

Background and aim. Percutaneous endoscopic gastrostomy (PEG) is a method of enteral nutrition. It is successfully used both in adults and children as well as in extremely low birth weight infants. The study aimed to assess the influence of gastrostomy (PEG) in children on life quality of their families.

Materials and methods. The study involved a group of 87 persons: parents of children with percutaneous endoscopic gastrostomy (PEG), including 71 women and 16 men aged between 23 and 53 years (mean $=32.03 ; \mathrm{SD}=6.12$; $\min .23$, max. 53 ). Group 1 comprised parents of children before PEG and Group 2 comprised parents of children after PEG. The children were treated at the Surgery Department, the Children's Memorial Health Institute in Warsaw. An anonymous, voluntary questionnaire study was performed between September 15, 2014 and February 27, 2015. STATISTICA 10.0, Mann-Whitney U test, and Wilcoxon test, $\alpha<0.05$.

Results. According to the opinion of 69 parents (79\%), the quality of life increased after PEG insertion. A subjective assessment of the quality of family life before PEG amounted to 3.23 and after PEG it increased to $3.79(p<0.001)$. As many as 75 study participants (85\%) said that the patient's condition had significantly improved and 69 parents (78\%) admitted that the nutritional status of their children had also improved. Nurses $(n=59,67 \%)$ and doctors $(n=53,60 \%)$ as well as other parents $(n=29,33 \%)$ constituted the main sources of knowledge about the disease and emotional support for parents of children with PEG.

Conclusions

1. The quality of children's lives and the functioning of their families after PEG insertion significantly improved among the study group.

2. The PEG insertion in children also substantially improved the general condition of children and their nutritional status, which could have significantly improved the quality of family life.

3. Parents' knowledge about the disease, its symptoms and signs, course and prognosis as well as support given to the families constitute an important factor in providing care for children with PEG. Therefore, the educational role of a nurse seems to be crucial.

KEYWORDS: enteral nutrition, quality of life, family, child 


\section{Wstęp}

Żywienie enteralne stanowi istotny element procesu leczniczego. Pozwala na uzupełnienie lub całkowite pokrycie zapotrzebowania na produkty odżywcze, niezbędne dla prawidłowego funkcjonowania organizmu i jest zalecane u pacjentów, którzy nie mogą być odżywiani drogą naturalną, pomimo zachowanej prawidłowej funkcji przewodu pokarmowego. W przewlekłym żywieniu enteralnym niezbędny jest bezpośredni dostęp do przewodu pokarmowego $\mathrm{w}$ postaci gastrostomii, gastrojejunostomii, jejunostomii [1, 2].

Przezskórna endoskopowa gastrostomia (PEG) jest jedną z metod żywienia dojelitowego. Jest ona z powodzeniem stosowana zarówno u dorosłych, jak i u dzieci, a także noworodków o skrajnie niskiej wadze urodzeniowej [3].

Po raz pierwszy została ona zastosowana w latach 80 . ubiegłego wieku poprzez wykorzystanie endoskopowej metody implantacji zgłębnika gastrostomijnego. W kolejnych latach nastąpił wszechstronny rozwój w zakresie rodzaju stosowanych zgłębników, mieszanek odżywczych, a wraz z tym dostępność i możliwość adaptacji żywienia do indywidualnych potrzeb pacjenta [4-6].

Jakość życia, związana z dobrostanem fizycznym, psychicznym i społecznym, stanowi istotny wyznacznik wydolności biopsychospołecznej chorego dziecka $i$ jego rodziny [6]. Jest wartością $w$ dużej mierze określaną jako subiektywne odczucie zależne od wielu zdarzeń, które w danej chwili są postrzegane przez pacjenta jako najistotniejsze dla jego życia. Pacjent, u którego zaistniała konieczność zastosowania gastrostomii odżywczej celem podjęcia żywienia enteralnego, najczęściej cierpi z powodu schorzeń przewlekłych, niepełnosprawności i innych problemów, które w sposób istotny wpływają na jego stan zdrowia i ogólne samopoczucie. Natomiast decyzja o żywieniu dziecka drogą dojelitową przy zastosowaniu stomii odżywczej jest dla rodzica sytuacją niezwykle trudną. Pacjenci mają zwykle za sobą liczne zabiegi i procedury medyczne, konieczność zastosowania gastrostomii jest przez wielu rodziców odbierana jako dodatkowy czynnik obciążający, wiążący się z koniecznością medykalizacji tak naturalnej potrzeby, jaką jest odżywianie. Obawy rodziców często są nieuzasadnione, a stan dzieci, u których występowały istotne zaburzenia odżywiania, po założeniu stomii w krótkim czasie ulega poprawie. Założenie gastrostomii ma istotne znaczenie dla jakości życia nie tylko pacjenta - dziecka, ale też jego rodziców i funkcjonowania rodziny [6].

W dostępnej, krajowej literaturze naukowej nie odnaleziono publikacji dotyczących oceny jakości życia rodziców i rodzin, u których dzieci założono gastrostomię. Dostępne publikacje dotyczą zazwyczaj poprawy stanu klinicznego dzieci po założeniu PEG lub oceny jakości życia samych dzieci.

\section{Cel pracy}

Celem pracy była próba oceny jakości życia rodzin dzieci z założoną gastrostomią (PEG).

\section{Materiał i metody}

Anonimowe, dobrowolne badania ankietowe za pomocą samodzielnie skonstruowanego kwestionariusza prowadzono od 15 września 2014 r. do 27 lutego 2015 r. Badaniami objęto rodziców dzieci, u których założono przezskórną gastrostomię odżywczą (PEG). Dzieci były pacjentami Poradni Chirurgicznej Instytutu Pomnika Centrum Zdrowia Dziecka w Warszawie. Przed rozpoczęciem badania ankietowego rodzice byli informowani przez osobę prowadzącą badania o jego celu oraz przebiegu. Badani rodzice byli kolejnymi osobami zgłaszającymi się ze swoimi dziećmi do Poradni Chirurgicznej i wyrażającymi zgodę na udział w badaniu, dlatego też można uznać tę grupę za reprezentatywną i dobraną losowo.

Autorzy badania nie uzyskali zgody Komisji Bioetycznej na udział w badaniu za względu na fakt, że Komisja Bioetyczna Warszawskiego Uniwersytetu Medycznego nie wydaje opinii na temat badań ankietowych i nieinwazyjnych, prowadzonych w grupach osób zdrowych [7].

\section{Charakterystyka badanej grupy}

Badaniami objęto 87 osób - rodziców dzieci, u których założono przezskórną gastrostomię odżywczą (PEG), w tym 71 kobiet $(81,61 \%)$ i 16 mężczyzn (18,39\%). Ankietowani byli w wieku od 23 do 53 lat (średnia wieku$=32,03 ; \mathrm{SD}=6,12 ; \mathrm{min} .23$, max. 53). Badani rodzice zostali podzieleni na dwie grupy: grupę rodziców dzieci przed założeniem PEG (grupa 1) oraz grupę rodziców dzieci po złożeniu PEG (grupa 2). Większość respondentów jako miejsce swojego zamieszkania wskazała obszary wiejskie $(n=38)$, najmniej osób wskazało na miasta od 100 do 500 tys. mieszkańców $(n=3)$. Najwięcej osób wskazało, że posiada wykształcenie wyższe $(n=30)$ oraz zawodowe $(n=26)$. Połowa rodziców zaznaczyła, iż obecnie nie pracuje $(n=44)$. W badanej grupie znalazło się również 25 osób wykonujących pracę umysłową, 11 osób pracujących fizycznie, 4 osoby utrzymujące się z działalności rolniczej oraz 3 osoby, które wskazały, iż przebywają na rencie lub emeryturze. Zdecydowaną większość stanowiły osoby żyjące w związku małżeńskim ( $n=70)$, najmniej było osób owdowiałych $(n=2)$. Dzieci ankietowanych rodziców to grupa w wieku od 1 do 17 lat (średnia wie$k u=7,20 ; S D=4,17)$. 


\section{Analiza statystyczna uzyskanych wyników}

Uzyskane wyniki badań ankietowych opracowano w programie Microsoft Excel. Analizę statystyczną uzyskanych wyników przeprowadzono w programie STATISTICA 10.0 (licencja Warszawskiego Uniwersytetu Medycznego). Ze względu na charakter analizowanych danych (dane jakościowe, nieparametryczne), które nie miały rozkładu normalnego - p>0,05 - analizowanego testem Shapiro-Wilka do analizy statystycznej uzyskanych wyników wykorzystano test statystyczny U Manna-Whitneya oraz test Wilcoxona. Za istotny statystycznie przyjęto poziom istotności $\alpha<0,05$.

\section{Wyniki}

W badanej grupie rodziców założenie u dziecka gastrostomii wpłynęło na poprawę jakości życia. Różnice w ocenie jakości życia rodziny przed założeniem PEG i po rozpoczęciu odżywiania tą drogą przedstawia tabela 1.

Tabela 1. Różnica w jakości życia rodziny przed i po założeniu PEG Table 1. Difference in life quality of family members before and after PEG

\begin{tabular}{|c|c|c|c|c|}
\hline $\begin{array}{c}\text { Założenie } \\
\text { gastrostomii/ } \\
\text { Gastrostomy } \\
\text { insertion }\end{array}$ & $\begin{array}{c}\text { Średnia/ } \\
\text { Mean }\end{array}$ & $\begin{array}{c}\text { Odchylenie } \\
\text { standardowe/ } \\
\text { Standard } \\
\text { deviation }\end{array}$ & $\begin{array}{c}\text { Wynik } \\
\text { testu Z/ } \\
\text { Z test results }\end{array}$ & $\begin{array}{c}\text { Poziom } \\
\text { istotności/ } \\
\text { significance } \\
\text { level }\end{array}$ \\
\hline $\begin{array}{c}\text { Przed założeniem } \\
\text { PEG/Before } \\
\text { Po założeniu PEG/ } \\
\text { After }\end{array}$ & 3,23 & 0,59 & 4,98 & $<0,001$ \\
\hline
\end{tabular}

*- skala $1-5 /{ }^{*}$ - scale $1-5$

Źródło: opracowanie własne

Source: author's own analysis

W grupie dzieci badanych rodziców gastrostomię odżywczą zakładano przede wszystkim z uwagi na schorzenia neurologiczne ( $n=63 ; 72,41 \%)$ (Tabela 2).

Tabela 2. Wskazanie do założenia gastrostomii odżywczej wśród dzieci ankietowanych rodziców

Table 2. Indications for PEG in children of respondents

\begin{tabular}{cc}
\hline $\begin{array}{c}\text { Wskazanie do założenia gastrostomii od- } \\
\text { żywczej w badanej grupie dzieci//ndications } \\
\text { for PEG in the study group }\end{array}$ & $\begin{array}{c}\text { Liczba osób (n)/(\%)/ } \\
\text { Number of persons }(n) /(\%)\end{array}$ \\
\hline $\begin{array}{c}\text { Choroba OUN/CNS diseases } \\
\text { Niedotlenienie OUN/CNS hypoxia }\end{array}$ & $63(72,41)$ \\
$\begin{array}{c}\text { Zaburzenia ssania, połykania/sucking } \\
\text { disorders, dysphagia }\end{array}$ & $19(29,89)$ \\
$\begin{array}{c}\text { Wada wrodzona górnego odcinka przewodu } \\
\text { pokarmowego/Congenital defect of the up- } \\
\text { per part of the gastrointestinal tract }\end{array}$ & $12(13,79)$ \\
Schorzenia przewodu pokarmowego/ \\
Gastrointestinal tract diseases \\
Zespół wad wrodzonych/
\end{tabular}

Ponad połowa $(65,52 \%)$ rodziców wskazała, iż musiała zrezygnować z pracy zawodowej na rzecz opieki nad chorym dzieckiem. Jednocześnie po założeniu u dziecka PEG jedynie 3 osoby (3,45\%) wróciły do pracy zawodowej. W tabeli 3 przedstawiono różnice w występowaniu określonych sytuacji życia codziennego przed i po założeniu PEG.

Tabela 3. Różnice w częstości występowania określonych sytuacji przed i po założeniu PEG

Table 3. Differences in incidence of particular situations before and after PEG

\begin{tabular}{|c|c|c|c|c|c|}
\hline $\begin{array}{l}\text { Dziedziny } \\
\text { życia/ } \\
\text { Areas } \\
\text { of life }\end{array}$ & $\begin{array}{l}\text { Założenie } \\
\text { gastrostomii/Ś } \\
\text { Gastrostomy } \\
\text { insertion }\end{array}$ & $\begin{array}{l}\text { Średnia/ } \\
\text { Mean }\end{array}$ & $\begin{array}{c}\text { Odchylenie } \\
\text { standardowe } \\
\text { Standard } \\
\text { deviation }\end{array}$ & $\begin{array}{c}\text { Wynik } \\
\text { / testu Z/ } \\
\text { Z test } \\
\text { results }\end{array}$ & $\begin{array}{l}\text { Poziom } \\
\text { istotności } \\
\mathrm{p} / \\
\text { Signifi- } \\
\text { cance level } \\
\text { (p) }\end{array}$ \\
\hline $\begin{array}{c}\text { Ograniczenia w czyn- } \\
\text { nościach, które mogła/ } \\
\text { mógł Pani/Pan wykonać } \\
\text { na rzecz innych człon- } \\
\text { ków rodziny/Limitations } \\
\text { in activities you could } \\
\text { do for other family } \\
\text { members. }\end{array}$ & $\begin{array}{c}\text { Przed/ } \\
\text { Before } \\
\text { Po/ } \\
\text { After }\end{array}$ & 3,06 & 1,13 & 3,15 & 0,002 \\
\hline $\begin{array}{c}\text { Przerwania codzien- } \\
\text { nych czynności typu } \\
\text { spożywanie posiłku, } \\
\text { wspólne prace domowe } \\
\text { oglądanie TV, rozmowa } \\
\text { z innymi domownikami/ } \\
\text { Interruption of everyday } \\
\text { activities such as having } \\
\text { meals, joint housework, } \\
\text { watching TV, conversa- } \\
\text { tions with other family } \\
\text { members. }\end{array}$ & $\begin{array}{l}\text { Przed/ } \\
\text { Before }\end{array}$ & 3,25 & 1,07 & 2,22 & 0,026 \\
\hline $\begin{array}{c}\text { Występowanie sytuacji } \\
\text { konfliktowych, nieporo- } \\
\text { zumienia w Pani/Pana } \\
\text { domu/Conflict situations } \\
\text { and misunderstandings } \\
\text { in your home. }\end{array}$ & $\begin{array}{l}\text { Przed/ } \\
\text { Before } \\
\text { Po/ } \\
\text { After }\end{array}$ & 1,97 & 0,88 & 2,26 & 0,024 \\
\hline $\begin{array}{l}\text { Gwałtowna zmiana/ } \\
\text { odwołanie planów } \\
\text { osobistych lub zawodo- } \\
\text { wych/Sudden change/ } \\
\text { cancellation of personal } \\
\text { or job plans. }\end{array}$ & $\begin{array}{l}\text { Przed/ } \\
\text { Before }\end{array}$ & 3,14 & 1,28 & 1,39 & 0,165 \\
\hline $\begin{array}{l}\text { Styl spędzania wolne- } \\
\text { go czasu, Pani/Pana } \\
\text { zainteresowania, hobby/ } \\
\text { How you spend your } \\
\text { free time, your interests } \\
\text { and hobbies. }\end{array}$ & $\begin{array}{l}\text { Przed/ } \\
\text { Before }\end{array}$ & 3,38 & 1,35 & 1,81 & 0,071 \\
\hline
\end{tabular}

Źródło: opracowanie własne

Source: author's own analysis

Rodziców zapytano ponadto o ograniczenia, które dotyczą samego dziecka, szczególnie w zakresie aktywności fizycznej i kontaktów z rówieśnikami. Jeśli chodzi o ograniczenie aktywności fizycznej - 42 osoby $(48,28 \%)$ wskazały, iż ono występuje. Badani, którzy wskazali, że ma ono miejsce, za przyczynę podawali podstawową chorobę dziecka 41 (47,13\%). 
Na ograniczenie kontaktu dziecka z rówieśnikami wskazało 37 osób (42,53\%), jednocześnie w grupie rodziców, która wskazała na takie ograniczenie, jako jego przyczynę w zdecydowanej większości wskazano podstawową jednostkę chorobową: 36 osób (41,38\%).

Rodzice zostali zapytani o obawy, jakie towarzyszyły im w związku z decyzją o założeniu u dziecka gastrotomii, i o częstość ich występowania. Wskazali, iż często bali się, że dziecko straci możliwość odżywiania drogą doustną, że nastąpi pogorszenie stanu jego zdrowia, co będzie wiązało się z koniecznością hospitalizacji. Największa grupa wskazała też, że czasami występowały obawy, czy wykonano dostatecznie dużo, by uchronić dziecko przed zabiegiem, oraz że będą występowały trudności z pielęgnacją PEG. Duża grupa wskazała, że czasami występowały obawy, iż w trakcie użytkowania stomii wystąpi problem, z którym samodzielnie nie będą potrafili sobie poradzić. Najrzadziej towarzyszyły im obawy związane z zaopatrzeniem w niezbędny sprzęt stosowany w żywieniu oraz w mieszaniny odżywcze (Tabela 4).

Po rozpoczęciu żywienia przez PEG istotnie zmniejszyły się obawy związane z utratą możliwości odżywiania dziecka drogą doustną oraz strach związany z koniecznością stosowania PEG. Różnice dotyczące częstości występowania określonych obaw rodziców przed i po założeniu PEG przedstawia tabela 4.

Tabela 4. Różnice w częstości w występowaniu określonych obaw rodziców przed i po założeniu PEG

Table 4. Differences in incidence of particular concerns of parents before and after PEG

\begin{tabular}{|c|c|c|c|c|c|}
\hline $\begin{array}{l}\text { Dziedziny/ } \\
\text { Areas }\end{array}$ & $\begin{array}{c}\text { Założenie } \\
\text { gastrostomii/ } \\
\text { Gastrostomy } \\
\text { insertion }\end{array}$ & $\begin{array}{l}\text { Średnia/ } \\
\text { Mean }\end{array}$ & $\begin{array}{c}\text { Odchylenie } \\
\text { standardowe/ } \\
\text { Standard } \\
\text { deviation }\end{array}$ & $\begin{array}{c}\text { Wynik } \\
\text { testu Z/ } \\
\text { Z test } \\
\text { results }\end{array}$ & $\begin{array}{c}\text { Poziom } \\
\text { istotności } \\
\mathrm{p} / \\
\text { Signifi- } \\
\text { cance level } \\
\text { (p) } \\
\end{array}$ \\
\hline $\begin{array}{l}\text { Przekonanie, } \\
\text { że dziecko } \\
\text { traci możliwość } \\
\text { odżywiania } \\
\text { drogą doustną/ } \\
\text { A belief that the } \\
\text { child loses pos- } \\
\text { sibility of eating } \\
\text { by mouth }\end{array}$ & Przed/Before & 3,63 & 1,25 & 3,98 & 0,001 \\
\hline $\begin{array}{l}\text { Lęk, niepokój } \\
\text { związany } \\
\text { z koniecznością } \\
\text { zastosowania } \\
\text { gastrostomii/ } \\
\text { Anxiety, fear that } \\
\text { gastrostomy is } \\
\text { required }\end{array}$ & Przed/Before & 2,83 & 1,40 & 2,86 & 0,004 \\
\hline
\end{tabular}

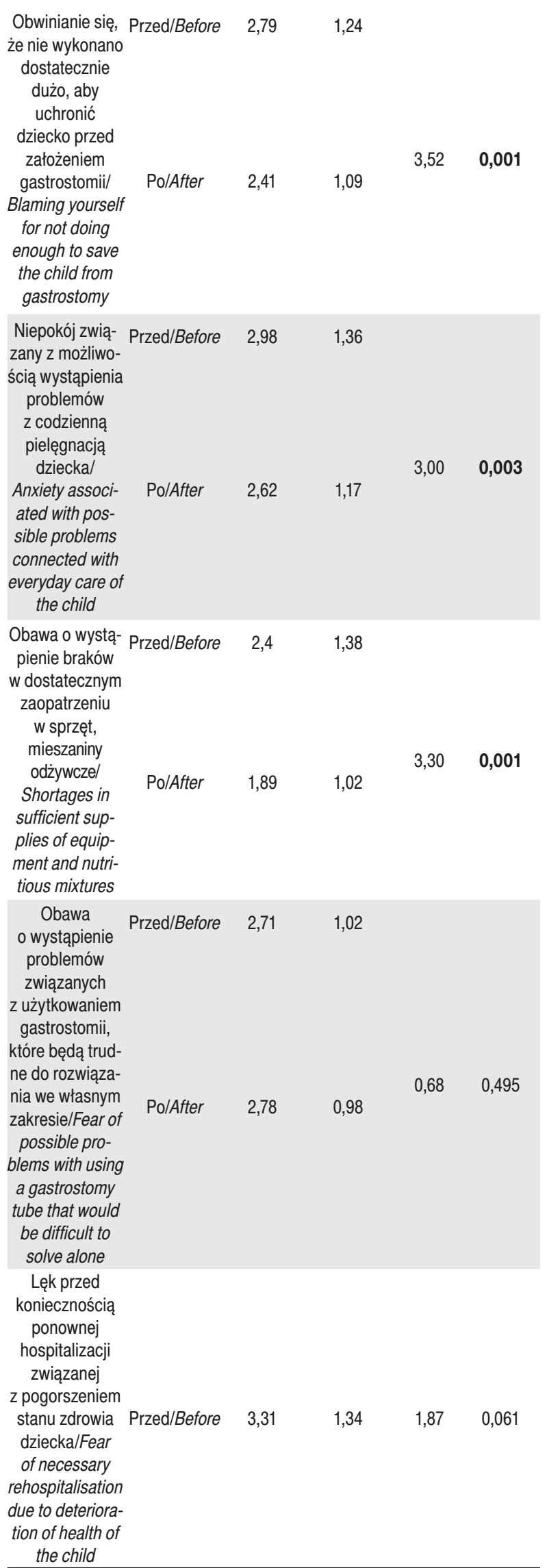

Źródło: opracowanie własne

Source: author's own analysis 
Zapytano również rodziców o wpływ rozpoczęcia żywienia dziecka przez PEG na poprawę jego ogólnego stanu zdrowia oraz stanu odżywienia. Zdecydowana większość wskazała, że stan zdrowia dziecka uległ poprawie (Tabela 5).

Tabela 5. Wpływ żywienia przez PEG na dzieci badanych Table 5. Influence of PEG on children

\begin{tabular}{|c|c|c|c|c|}
\hline \multirow[t]{2}{*}{ Odpowiedzi/Answers } & \multicolumn{2}{|c|}{$\begin{array}{c}\text { Poprawa } \\
\text { stanu zdrowia/ } \\
\text { Improvement } \\
\text { of health status }\end{array}$} & \multicolumn{2}{|c|}{$\begin{array}{l}\text { Poprawa stanu } \\
\text { odżywienia/ } \\
\text { Improvement of } \\
\text { nutritional status }\end{array}$} \\
\hline & $\mathrm{N}$ & $\%$ & $\mathrm{~N}$ & $\%$ \\
\hline $\begin{array}{c}\text { Zdecydowanie tak/ } \\
\text { strongly yes }\end{array}$ & 38 & 43,68 & 46 & 52,87 \\
\hline Raczej tak/rather yes & 37 & 42,53 & 23 & $26,44 /$ \\
\hline $\begin{array}{c}\text { Trudno powiedzieć/ } \\
\text { Difficult to say }\end{array}$ & 11 & 12,64 & 16 & 18,39 \\
\hline Raczej nie/rather not & 0 & 0,00 & 1 & 1,15 \\
\hline $\begin{array}{l}\text { Zdecydowanie nie/ } \\
\text { strongly not }\end{array}$ & 1 & 1,15 & 1 & 1,15 \\
\hline
\end{tabular}

Źródło: opracowanie własne

Source: author's own analysis

Jednocześnie rodzice wskazali, kto był dla nich źródłem największego wsparcia emocjonalnego w związku z ich obawami przed rozpoczęciem odżywiania dziecka przez gastrostomię. Najczęściej wymieniano pielęgniarkę, lekarza oraz innego rodzica (Tabela 6).

Tabela 6. Źródła wsparcia emocjonalnego w związku z obawami związanym z założeniem u dziecka PEG

Table 6. Source of emotional support in concerns with PEG insertion in children

\begin{tabular}{ccc}
\hline Odpowiedzi/Answers & $\mathrm{N}$ & $\%$ \\
\hline Pielegniarka/Nurse & 59 & 67,82 \\
\hline Psycholog/Psychologist & 5 & 5,75 \\
\hline Inny rodzic/Other parent & 29 & 33,33 \\
Lekarz/Physician & 53 & 60,92 \\
Rodzina/Family & 7 & 8,05 \\
Literatura, Internet/Literature, Internet & 8 & 9,20 \\
\hline
\end{tabular}

Źródło: opracowanie własne

Source: author's own analysis

W opinii badanych personel pielęgniarski i lekarski był również największym źródłem wiedzy na temat zasad pielęgnacji dziecka po założeniu gastrostomii. Często wskazywano również na rolę innych osób, które żywią własne dziecko przez gastrostomię, oraz na literaturę i Internet (Tabela 7 ).
Tabela 7. Źródła wiedzy na temat pielęgnacji dziecka po założeniu PEG Table 7. Source of knowledge about care of children with PEG tubes

\begin{tabular}{ccc}
\hline Odpowiedzi/Answers & $\mathrm{N}$ & $\%$ \\
\hline Lekarz/Physician & 61 & 70,11 \\
Pielęgniarka/Nurse & 70 & 80,46 \\
\hline $\begin{array}{c}\text { Fachowa literatura, czasopisma, Internet/ } \\
\text { Specialised literature, journals, Internet }\end{array}$ & 23 & 26,44 \\
$\begin{array}{c}\text { Inne osoby, które odżywiają dziecko przez gastrosto- } \\
\text { mię/Other persons who feed children through } \\
\quad \text { a PEG tube }\end{array}$ & 34 & 39,08 \\
$\quad$ Rodzina/Family & 4 & 4,60 \\
Znajomi/Friends & 2 & 2,30 \\
\hline
\end{tabular}

Źródło: opracowanie własne

Source: author's own analysis

Zdecydowana większość wskazała, że dzieci są objęte specjalistyczną opieką w miejscu zamieszkania, rodzice wymieniali też lekarza rodzinnego, poradnię żywieniową i gastrologiczną oraz hospicjum (Tabela 8).

Tabela 8. Rodzaj placówki medycznej sprawującej opiekę nad dzieckiem Table 8. Type of medical centre that provides care for the child

\begin{tabular}{|c|c|c|c|}
\hline Odpowiedzi/Answers & $\mathrm{N}$ & \% ogółu & $\%$ grupy \\
\hline Poradnia żywieniowa/Nutrition clinic & 29 & 33,33 & 36,71 \\
\hline Poradnia gastrologiczna/Gastrology clinic & 19 & 21,84 & 24,05 \\
\hline Lekarz rodzinny/General practicioner & 62 & 71,26 & 78,48 \\
\hline Pielęgniarka środowiskowa/Health visitor & 4 & 4,60 & 5,06 \\
\hline $\begin{array}{c}\text { Pielęgniarka opieki długoterminowej/ } \\
\text { Long-term care nurse }\end{array}$ & 1 & 1,15 & 1,27 \\
\hline Hospicjum domowe/Home hospice & 15 & 17,24 & 18,99 \\
\hline Poradnia chirurgiczna/Surgical clinic & 3 & 3,45 & 3,80 \\
\hline $\begin{array}{c}\text { Poradnia pulmonologiczna/ } \\
\text { Pulmonary clinic }\end{array}$ & 1 & 1,15 & 1,27 \\
\hline Poradnia kardiologiczna/Cardiology clinic & 2 & 2,30 & 2,53 \\
\hline Poradnia neurologiczna/ Neurological clinic & 5 & 5,75 & 6,33 \\
\hline
\end{tabular}

Źródło: opracowanie własne

Source: author's own analysis

Dzieci ankietowanych rodziców odżywiane były przez gastrostomię przez okres od pół roku do 6 lat, średni czas odżywiania przez gastrostomię badanych dzieci wyniósł 2,5 roku (SD=1,3 roku, min. 0,5; max. 6).

Rodziców zapytano o problemy, jakie towarzyszyły im w okresie odżywiania dziecka przy pomocy gastrostomii, oraz o częstość ich występowania. Najwięcej osób wskazało, że problemy czasami mają miejsce. W grupie osób, które wskazały na problemy z odżywianiem przez PEG, najczęściej wymieniano wymioty i bóle brzucha (Tabela 9 i 10). 
Tabela 9. Częstość występowania problemów z odżywianiem dziecka przez gastrostomię

Table 9. Incidence of problems in feeding children through a gastrostomy tube

\begin{tabular}{ccc}
\hline Odpowiedzi/Answers & N & $\%$ \\
\hline Nigdy/Never & 25 & 28,74 \\
Czasami/Sometimes & 47 & 54,02 \\
Często/Often & 13 & 14,94 \\
Bardzo często/Very often & 1 & 1,15 \\
Stale/Always & 1 & 1,15 \\
\hline
\end{tabular}

Źródło: opracowanie własne

Source: author's own analysis

Tabela 10. Rodzaj problemów występujących w czasie odżywiania dziecka przez gastrostomię

Table 10. Types of problems in feeding children through a gastrostomy tube

\begin{tabular}{ccc}
\hline Odpowiedzi/Answers & $\mathrm{N}$ & $\%$ \\
\hline Zaleganie/Food retention & 2 & 2,30 \\
Ulewanie/Posseting & 8 & 9,20 \\
\hline Wymioty/Vomiting & 13 & 14,94 \\
\hline Ból brzucha/Abdominal pain & 12 & 13,79 \\
\hline Zaparcia/Constipation & 5 & 5,75 \\
$\quad$ Biegunki/Diarrhea & 7 & 8,05 \\
\hline $\begin{array}{c}\text { Brak możliwości podaży zalecanej liczby kalorii/ } \\
\text { Impossibility of supplying the recommended amount } \\
\text { of calories }\end{array}$ & 1 & 1,15 \\
\hline
\end{tabular}

Źródło: opracowanie własne

Source: author's own analysis

W badanej grupie jako najczęstsze problemy z użytkowaniem gastrostomii wskazano ziarninę i objawy stanu zapalnego. Wypadnięcie lub zatkanie się gastrostomii występowały rzadko (Tabela 11).

Tabela 11. Rodzaj problemów związanych z użytkowaniem gastrostomii Table 11. Types of problems in using a gastrostomy tube

\begin{tabular}{ccc}
\hline Odpowiedzi/Answers & N & $\%$ \\
\hline Ziarnina/Granulation tissue & 28 & 32,18 \\
Stan zapalny//Inflammation & 21 & 24,14 \\
\hline $\begin{array}{l}\text { Wypadnięcie gastrostomii/ } \\
\text { Gastrostomy tube prolapse }\end{array}$ & 6 & 6,90 \\
Zatkanie gastrostomii/Gastrostomy tube occlusion & 3 & 3,45 \\
\hline
\end{tabular}

Źródło: opracowanie własne

Source: author's own analysis

W opinii badanych rodziców po założeniu gastrostomii jakość życia dziecka oraz rodziny uległa znaczącej poprawie (Tabela 12).
Tabela 12. Opinia badanych na temat poprawy jakości życia dziecka oraz rodziny po założeniu PEG

Table 12. Opinions of study participants on improvement of quality of life of the child and family members after PEG insertion

\begin{tabular}{ccccc}
\hline Odpowiedzi/Answers & \multicolumn{2}{c}{$\begin{array}{c}\text { Jakość życia } \\
\text { dziecka/ } \\
\text { Quality of life } \\
\text { of the child }\end{array}$} & \multicolumn{2}{c}{$\begin{array}{c}\text { Jakość życia } \\
\text { rodziny/ } \\
\text { Quality of life of } \\
\text { family members }\end{array}$} \\
& $\mathrm{N}$ & $\%$ & $\mathrm{~N}$ & $\%$ \\
\hline Zdecydowanie tak/strongly yes & 34 & 39,08 & 22 & 25,29 \\
\hline Raczej tak/rather yes & 35 & 40,23 & 39 & 44,83 \\
\hline Trudno powiedzieć/Difficult to say & 12 & 13,79 & 18 & 20,69 \\
\hline Raczej nie/rather not & 6 & 6,90 & 8 & 9,20 \\
\hline Zdecydowanie nie/strongly not & 0 & 0,00 & 0 & 0,00 \\
\hline
\end{tabular}

Źródło: opracowanie własne

Source: author's own analysis

\section{Dyskusja}

Leczenie żywieniowe jest ważnym elementem procesu terapeutycznego, stosowanym w przypadku schorzeń przebiegających z niedożywieniem, zarówno w przypadku chorób przewlekłych, jak i stanów ostrych. Żywienie prowadzone jest drogą dojelitową lub pozajelitową [1-5].

W pediatrii wśród schorzeń stanowiących wskazanie do stosowania leczenia żywieniowego dojelitowego na pierwszym miejscu wymienia się zaburzenia neurologiczne [4-6]. Znajduje to odzwierciedlenie w wynikach prezentowanego badania, które wskazują, iż największą grupę dzieci, u których zastosowano dojelitową formę żywienia, stanowią pacjenci z chorobami neurologicznymi, w tym niedotlenieniem OUN.

Ważnym problemem u dzieci chorujących przewlekle jest ograniczenie ich aktywności fizycznej, przede wszystkim brak możliwości przemieszczania się [8-10]. W prezentowanych badaniach prawie połowa rodziców wskazała na ograniczoną aktywność fizyczną dziecka, w większości na skutek choroby podstawowej. Implantacja stomii odżywczej zwiększa możliwość przemieszczania się dziecka i korzystnie wpływa na jego aktywność.

Jak wskazuje Łyszkowska, żywienie dojelitowe wpływa na poprawę stanu chorego [11]. Także w badaniach własnych wykazano, iż u większości pacjentów po założeniu PEG osiągnięto cel w postaci poprawy stanu ich zdrowia, a 44\% rodziców wskazało na zdecydowaną poprawę.

Żywienie przy pomocy gastrostomii może trwać wiele miesięcy, a nawet lat [12-17]. Potwierdzają to aktualne wyniki: w badanej grupie średni czas żywienia przez PEG wynosił 2,5 roku. Jednocześnie ta forma żywienia nie wyklucza możliwości kontynuacji podaży pokarmu drogą doustną [12-17]. Jest to istotne, ponieważ wielu rodziców wskazało, iż przed założeniem gastrostomii często mieli obawy, że dziecko straci możliwość odży- 
wiania tą drogą. Po założeniu PEG obawy te znacznie się zmniejszyły.

Sam zabieg założenia stomii jest uznany za bezpieczny i obarczony niskim ryzykiem wystąpienia powikłań. Zdecydowanie więcej problemów wiąże się z pielęgnacją PEG i prowadzeniem żywienia przez rodziców dziecka [15-20]. Również w grupie badanej odżywianie dziecka przez PEG okresowo wiązało się z występowaniem problemów, nie były one jednak częste. Wśród najczęściej wymienianych problemów znalazły się wymioty, dolegliwości bólowe ze strony jamy brzusznej oraz ulewanie. Ponadto wskazano na inne problemy związane z użytkowaniem PEG, w tym obecność ziarniny i pojawienie się stanu zapalnego. Wypadnięcie PEG czy jego zatkanie wymieniano rzadko.

W badaniach własnych szczególną uwagę poświęcono jakości życia rodzin dzieci, u których wytworzono gastrostomię odżywczą. Należy zaznaczyć przy tym, że - tak jak wskazuje Telka - jakość życia w okresie choroby niezwykle trudno jest zdefiniować [18]. Choroba dziecka, zwłaszcza ta o charakterze przewlekłym i niepewnym rokowaniu, zaburza funkcjonowanie rodziny $[18,19]$. Wyniki badań własnych wskazały, że aż 66\% rodziców musiało zrezygnować z kariery zawodowej, by podjąć się opieki nad chorym dzieckiem.

Wyniki badania wskazują, iż w dużej grupie przed założeniem PEG u dziecka warunki życia, relacje z rówieśnikami, rozwój osobisty i wypoczynek dziecka były zaburzone. Po założeniu gastrostomii nastąpiła poprawa funkcjonowania rodziny. $\mathrm{Na}$ bardzo częste ograniczenie w wykonywaniu różnych czynności na rzecz innych członków rodziny po założeniu PEG wskazało jedynie $9 \%$ badanych, natomiast na ograniczenie w realizacji własnych zainteresowań - $21 \%$. Uważa się, że choroba dziecka, lęk i bezradność rodziców z nią związane mogą być przyczyną konfliktów w rodzinie i pogorszenia jakości życia [18, 19]. Co ciekawe, sytuacje konfliktowe $w$ rodzinie przed założeniem dziecku PEG w opinii badanych nie miały miejsca nigdy lub występowały bardzo rzadko, a po założeniu stomii nigdy nie występowały u $32 \%$ badanych i bardzo rzadko w grupie $45 \%$. Większość badanych (68\%) wskazała na dobrą jakość życia, w tym 34 osoby uznały, iż po założeniu PEG jakość życia zdecydowanie uległa poprawie, a 36 osób zaznaczyło, że raczej tak. Przed implantacją PEG na dobrą jakość życia wskazały zaledwie 24 osoby, po jego założeniu 59 osób.

Ważnym elementem w opiece nad dzieckiem i rodziną dziecka przewlekle chorego lub dziecka z niepełnosprawnością, u którego zachodzi konieczność założenia PEG, jest wiedza rodziców na temat choroby, jej objawów, przebiegu i rokowania, a także udzielone rodzinie wsparcie [8-15]. Wśród najczęściej wskazywa- nych źródeł wiedzy na temat pielęgnacji dziecka z PEG wymieniano personel pielęgniarski, lekarzy oraz inne osoby posiadające doświadczenie w żywieniu własnego dziecka przez PEG. Ponad 90\% dzieci jest objętych profesjonalną opieką w miejscu zamieszkania. Najwięcej osób wskazało, iż opiekę tę pełni lekarz rodzinny, często wskazywano poradnię żywieniową, poradnię gastrologiczną oraz hospicjum.

\section{Wnioski}

1. Jakość życia dziecka oraz funkcjonowanie rodziny po założeniu gastrostomii odżywczej PEG u dziecka uległa w badanej grupie istotnej poprawie.

2. Założenie gastrostomii odżywczej PEG u dziecka znacznie poprawiło ogólny stan zdrowia dziecka i stan jego odżywienia, co mogło istotnie wpływać na wzrost jakości życia rodziny.

3. Ważnym elementem $w$ opiece nad dzieckiem z gastrostomią odżywczą PEG jest wiedza rodziców na temat choroby, jej objawów, przebiegu i rokowania, a także udzielone rodzinie wsparcie, dlatego też niezwykle istotna wydaje się być edukacyjna rola pielęgniarki.

\section{Piśmiennictwo}

1. Laskowska J. Leczenie żywieniowe u dzieci. Nowa Pediatr 2007; 3: 60-62.

2. Matuszczyk M, Szczepański M, Janowska A. Domowe żywienie dojelitowe dzieci ze schorzeniami gastroenterologicznymi. Post Żyw Klin 2011; (20) 4: 25-30.

3. Löser Ch. Consensus statement. ESPEN guidelines on artificial enteral nutrition - percutaneous endoscopic gastrostomy (PEG). Clin Nutr 2005; 24: 848-861.

4. Wiernicka A, Szczepański M, Rybak A. Gastrostomia odżywcza a refluks żołądkowo-przełykowy u dzieci. Stan Med., Pediatr 2013; 11: 234-237.

5. Ponsky J. The Development of PEG: How it was. J Int Gastroeterol 2011; 1(2): 88-89.

6. Jabłoński J, Czajka P, Białas A, Lewandowska M. Przezskórna endoskopowa gastrostomia u dzieci - szansa na lepsze życie czy zło konieczne? Pediatr Med Rodz 2010; 6 (3): 2014-2010.

7. Opinia Komisji Bioetycznej Warszawskiego Uniwersytetu Medycznego http://komisja-bioetyczna.wum. edu.pl/content/szczeg\%C3\%B3\%C5\%82owe-informacje-oraz-wzory-dokument\%C3\%B3w. (data dostępu: 05.02.2016).

8. Socha J, Socha P, Weker H, Neuhoff-Murawska J. Żywienie dzieci a zdrowie wczoraj, dziś, jutro. Pediatr Współcz. Gastroeneterologia, Hepatologia i Żywienie Dziecka 2010; (12) 1:34-37.

9. Książyk J. i wsp. Zalecenia leczenia żywieniowego u dzieci z przewlekłymi chorobami układu nerwowego. Neurol Dziec 2011; (20) 4: 79-86.

10. Laskowska J. Żywienie pozajelitowe u dzieci. Farmacja Polska 2009; 7: 499-504.

11. Łyszkowska M, Popińska K, Książyk J. Wskazania do zastosowania przezskórnej endoskopowej gastrostomii (PEG) u dzieci. Post Żyw Klin 2006; 1 (1): 26-28. 
12. Grabowski K, Strutyńska-Karpińska M, Taboła R, Wierzbicki J. Przydatność i sposoby wytworzenia odżywczych przetok żołądkowych i jelitowych u chorych leczonych operacyjnie z powodu bliznowej poparzeniowej niedrożności górnego odcinka przewodu pokarmowego. Adva Clin and Experimental Med 2005; (14) 1: 85-90.

13. Toporowska-Kowalska E, Jabłoński J, Wąsowska-Królikowska K. Przezskórna endoskopowa gastrojejunostomia (PEG-PEJ) u dzieci - doświadczenia własne. Pediatr Pol 2007; (82) 2: 110-113.

14. Szczygieł B. Leczenie żywieniowe - Postępy 2012. Med Prakt Chir 2013; 2: 47.

15. Aftyka A, Rozalska-Walaszek I, Lesiuk W, Lesiuk L. Leczenie żywieniowe dzieci przedwcześnie urodzonych, hospitalizowanych w Oddziale Intensywnej Terapii Noworodka, ze szczególnym uwzględnieniem zadań pielęgniarki. Piel XXI w 2011; 3 (36): 35-39.

16. Karwowska K, Hartmann-Sobczyńska R, Mańkowska-Wierzbicka D. Preparaty do żywienia dojelitowego - jak wybrać dietę w oddziale intensywnej terapii? Farm Współ 2011; 4: 75-79.

17. El-Matary W. Percutaneous endoscopic gastrostomy in children. Can J Gastroenterol 2008; 22 (12): 993-8.
18. Telka E. Ocena jakości życia w wymiarze psychologicznym, zdrowotnym i społecznym, Nowa Med. 2013; 4: 184-186.

19. Ostrzyżek A. Jakość życia w chorobach przewlekłych. Probl Hig Epidemiol 2008; 89(4): 467-470.

20. Barczykowska E, Szczukowska B, Kurylak A. Przezskórna endoskopowa gastrostomia u dzieci - praktyka pielęgniarska oparta na faktach. Piel Chir Angiol 2011; 4: 181-186.

Artykuł przyjęty do redakcji: 21.04.2016

Artykuł przyjęty do publikacji: 07.07.2016

Źródło finansowania: Praca nie jest finansowana z żadnego źródła. Konflikt interesów: Autorzy deklarują brak konfliktu interesów.

\section{Adres do korespondencji:}

Joanna Gotlib

ul. Żwirki i Wigury 61

02-091 Warszawa

tel.: 225720 490, fax: 225720491

e-mail: joanna.gotlib@wum.edu.pl

Zakład Dydaktyki i Efektów Kształcenia

Warszawski Uniwersytet Medyczny 